University of Nebraska - Lincoln

DigitalCommons@University of Nebraska - Lincoln

Public Health Resources

Public Health Resources

2005

\title{
Genome size and organization in the blacklegged tick, Ixodes scapularis and the Southern cattle tick, Boophilus microplus
}

\author{
A. J. Ullmann \\ Division of Vector-Borne Infectious Diseases, National Center for Infectious Diseases, Centers for Disease \\ Control and Prevention, Fort Collins, CO, USA \\ C. M. R. Lima \\ Division of Vector-Borne Infectious Diseases, National Center for Infectious Diseases, Centers for Disease \\ Control and Prevention, Fort Collins, CO, USA \\ F. D. Guerrero \\ USDA-ARS Knipling-Bushland U.S. Livestock Insects Research Laboratory, Kerrville, TX, USA \\ J. Piesman \\ Division of Vector-Borne Infectious Diseases, National Center for Infectious Diseases, Centers for Disease \\ Control and Prevention, Fort Collins, CO, USA \\ W. C. Black IV \\ Department of Microbiology, Immunology and Pathology, Colorado State University, Fort Collins, CO, USA
}

Follow this and additional works at: https://digitalcommons.unl.edu/publichealthresources

Part of the Public Health Commons

Ullmann, A. J.; Lima, C. M. R.; Guerrero, F. D.; Piesman, J.; and Black IV, W. C., "Genome size and organization in the blacklegged tick, Ixodes scapularis and the Southern cattle tick, Boophilus microplus" (2005). Public Health Resources. 111.

https://digitalcommons.unl.edu/publichealthresources/111

This Article is brought to you for free and open access by the Public Health Resources at DigitalCommons@University of Nebraska - Lincoln. It has been accepted for inclusion in Public Health Resources by an authorized administrator of DigitalCommons@University of Nebraska - Lincoln. 


\section{Genome size and organization in the blacklegged tick, Ixodes scapularis and the Southern cattle tick, Boophilus microplus}

\author{
A. J. Ullmann*, C. M. R. Lima*, F. D. Guerrero†, \\ J. Piesman* and W. C. Black IV ‡ \\ *Division of Vector-Borne Infectious Diseases, National \\ Center for Infectious Diseases, Centers for Disease Control \\ and Prevention, Fort Collins, CO, USA;†USDA-ARS \\ Knipling-Bushland U.S. Livestock Insects Research

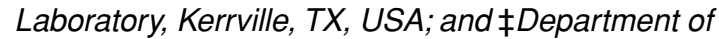 \\ Microbiology, Immunology and Pathology, Colorado State \\ University, Fort Collins, CO, USA
}

\begin{abstract}
Genome sizes and the organization of repetitive DNA were determined in the hard ticks Ixodes scapularis and Boophilus microplus using reassociation kinetics. The I. scapularis genome contains $2.15 \mathrm{pg}\left(2.1 \times 10^{3}\right.$ $\mathrm{Mbp}$ ) of DNA and consists of no foldback (FB), $27 \%$ highly repetitive (HR), 39\% moderately repetitive (MR), and $34 \%$ unique DNA. The B. microplus genome contains $7.5 \mathrm{pg}\left(7.1 \times 10^{3} \mathrm{Mbp}\right) \mathrm{DNA}$, and consists of $0.82 \%$ FB, $31 \% \mathrm{HR}, 38 \% \mathrm{MR}$, and $30 \%$ unique DNA. In both species, repetitive sequences occur in a mixture of long and short period interspersion but most $(65-80 \%)$ of the DNA follows a pattern of short period interspersion. Genome size and organization in the three tick species so far examined are distinct from other arthropods in having a greater proportion of MR, a lower proportion of unique and HR DNA of very low sequence complexity.
\end{abstract}

Keywords: genome size, genome organization, hard ticks, reassociation kinetics.

\section{Introduction}

Ticks are second only to mosquitoes in the ability to transmit pathogens to vertebrates (Sonenshine, 1991). Ixodes scapularis, the blacklegged tick, is an important vector of the

\footnotetext{
doi: 10.1111/j.1365-2583.2005.00551.x
}

Received 17 November 2004; accepted after revision 24 November 2004. Correspondence: Amy J. Ullmann, Centers for Disease Control and Prevention, Division of Vector-Borne Infectious Diseases, PO Box 2087, Rampart Road, Foothills Campus, Fort Collins, CO 80522, USA. Tel.: + 1970225 4251; fax: + 1970225 4257; e-mail: aff1@cdc.gov aetiologic agents causing several human diseases including Lyme disease (Borrelia burgdorferi), human granulocytic anaplasmosis (Anaplasma phagocytophilum), and human babesiosis (Babesia microti) (Belongia, 2002; Krause, 2002). In addition, potential pathogens such as a variant of Powassan virus have been detected in I. scapularis (Ebel et al. 2001). Boophilus microplus, the Southern cattle tick, has long been recognized as one of the most important vectors of the veterinary disease agents that cause bovine babesiosis in tropical and subtropical regions of the world (Bram et al., 2002). Despite their tremendous impact on human and animal health, little is understood about the genetics underlying phenotypic characteristics such as host seeking, host selection, attachment and feeding, salivation, oral and transovarial transmission of pathogens, development, physiology and reproduction. A number of insect genomes have been or are in the process of being sequenced. Furthermore a wide range of tools have been developed for assessing gene function in insects. However, it has been c. 500 million years (MY) since arthropods in the subphylum Mandibulata [containing the order Hexapoda (insects)] shared a common ancestor with species in the subphylum Chelicerata [containing the order Acari, suborder Ixodida (ticks)]. It is likely that significant divergence has occurred between ticks and insects in aspects of genome structure, promoters, transcription and translation and gene function.

There are $c .830$ species of ticks (Sonenshine, 1991). These are distributed in two families: Argasidae (soft ticks) with c. $170 \mathrm{spp}$. and Ixodidae (hard ticks) with c. $660 \mathrm{spp}$. The Ixodidae consists of two major subdivisions: the Prostriata (c. $240 \mathrm{spp}$. in the subfamily Ixodinae) and the Metastriata; c. $420 \mathrm{spp}$. in four subfamilies: Bothriocrotinae (Klompen et al., 2002), Amblyomminae, Haemaphysalinae, and Rhipicephalinae containing Hyalomma spp. (Klompen et al., 2000). Most soft and hard tick species are ectoparasites on wildlife but $c$. fifty species are important pests acting either as vectors of pathogens in epizootic or enzootic cycles or as causes of exsanguination (Sonenshine, 1991). Because of their tremendous impact on human and animal health, respectively, I. scapularis and B. microplus are two hard ticks for which white papers for whole genome sequencing have or are in the process of being approved. The I. scapularis 
genome has recently been selected for sequencing (Catherine Hill, International Ixodes scapularis Sequencing Committee, pers. comm.).

Determination of genome size and the organization of repetitive elements in a given genome is an important precursor to whole genome sequencing. Knowledge of genome size indicates the numbers of libraries and the amount of shotgun sequencing that will be needed to obtain complete genome coverage. Eukaryotic genomes consist of unique (single copy) sequences interspersed within a variety of repetitive sequences (Davidson et al., 1975). Repetitive sequences are composed of foldback (FB), highly repetitive (HR) and moderately repetitive (MR) elements. FB DNA is composed of tandem repeated sequences with inverted repeats that fold back on themselves more rapidly than predicted by two-strand reassociation kinetics. HR DNA is composed of sequence families that exist as tandem or dispersed repeats in a wide range of abundances from 1000 to $>100000$ copies. MR sequences have a lower abundance (from 10 to 1000 copies) and include transposable elements and members of multigene families (e.g. ribosomal RNA cistron).

Two basic patterns of HR and MR organization are found in eukaryotes (Davidson et al., 1975). Short period interspersion describes a pattern of single-copy sequences 1000 $2000 \mathrm{bp}$ in length that alternate with short (200-600 bp) and moderately long (400-1000 bp) repetitive sequences. This pattern of organization is characteristic of the majority of animal species. Long period interspersion describes a pattern of long (5600 bp) repeats alternating with very long (13 kbp) uninterrupted stretches of unique sequences. The long repeats generally consist of a mixture of long and short HR and MR elements (Crain et al., 1976). Long period interspersion is characteristic of most species with small genomes (0.10-0.50 pg) (Samols \& Swift, 1979), however, avian genomes are relatively large (1-2 pg) and exhibit long period interspersion (Epplen et al., 1978, 1979). As genome size increases repetitive DNA generally occurs in a continuum between long and short period interspersion (Black \& Rai, 1988). Knowledge of HR and MR amount and organization predicts the frequency with which unique, presumably coding, sequences will be found in genomes.

Genome size has already been reported in the metastriate tick Amblyomma americanum to be $c .1 .08 \mathrm{pg}\left(1.04 \times 10^{3}\right.$ Mbp) (Palmer et al., 1994). This is a relatively large genome for an arthropod (Palmer \& Black, 1997), furthermore repetitive elements were distributed in a pattern of long period interspersion which is unusual for such a large genome. Herein we describe genome size and the organization of repetitive elements in $I$. scapularis and $B$. microplus.

\section{Results and discussion}

The reassociation rate of Escherichia coli DNA was measured to calibrate our methods and equipment and to act as a genome size standard. Reassociation rate is typically expressed in terms of molarity of single-stranded DNA multiplied by the time of reassociation in seconds. For comparison purposes, the $C_{o} t_{1 / 2}$ is usually reported. This is the number of mole-seconds at which $50 \%$ of the single stranded DNA is reassociated for a particular species or in a particular fraction of the genome in a species. The $C_{o} t_{1 / 2}$ of $2.67 \mathrm{~mol}$ s estimated in the present study (Table 1) falls well within the 2.2-2.8 mol s range of estimates from previous studies (Lewin, 1980).

Ixodes scapularis and B. microplus fragments sonicated to 300 or 1800 bp were allowed to reassociate, and the proportions of single and double stranded DNA at increasing $C_{o} t$ values were assayed by hydroxyapatite chromatography (Britten et al., 1974). Nonlinear least squares regression was used to estimate reassociation rates and proportions of $\mathrm{FB}, \mathrm{HR}, \mathrm{MR}$ and unique sequences. The best fit for short fragments in both species was obtained with a model consisting of four components. The Y-intercept below a $\log _{10}$ $\left(E C_{o} t\right)$ of -2 estimates the amount of FB sequences. The fastest reassociating fraction between -2 and $0 \log _{10}\left(E C_{o} t\right)$ consists primarily of HR DNA. The fraction between 0 and $2 \log _{10}\left(E C_{0} t\right)$ consists primarily of MR DNA. The slowest reassociation between 2 and $4 \log _{10}\left(E C_{o} t\right)$ occurs primarily among unique sequences (Palmer \& Black, 1997). For both species, the best fit with long fragments was obtained with a three component model consisting of $\mathrm{FB}, \mathrm{HR}$ and unique DNA. Reassociation data and the least squares fit for short and long DNA fragments of $I$. scapularis and $B$. microplus are plotted in Figs 1 and 2. Amounts and reassociation rates of FB, HR, MR and unique sequences appear in Table 1.

The short fragment curve indicates that the I. scapularis genome contains $66 \%$ repetitive DNA $(27 \%$ HR and $39 \%$

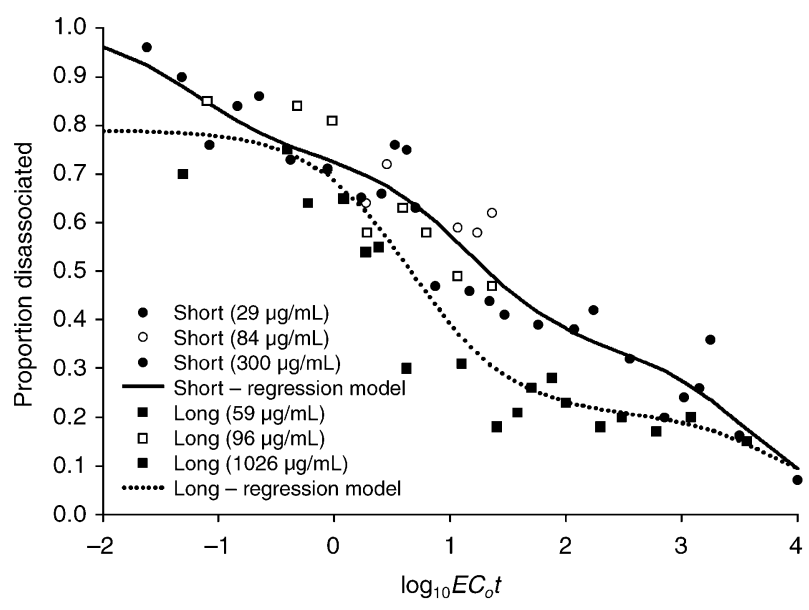

Figure 1. Reassociation of Ixodes scapularis DNA sheared to short and long fragment sizes. The short curve represents the least squares solution with four components [foldback (FB), highly repetitive (HR), moderately repetitive (MR), and unique sequences]. The long curve represents the least squares solution with three components (FB, HR, and unique sequences). 
Table 1. DNA reassociation kinetic analysis of E. coli, I. scapularis and B. microplus

\begin{tabular}{|c|c|c|c|c|}
\hline Species & $\begin{array}{l}\text { Proportions of } \\
\text { fragments (\%) }\end{array}$ & $\begin{array}{l}\text { Reassociation } \\
\text { rate }(1 / \mathrm{mol} \mathrm{s})\end{array}$ & $\begin{array}{l}C_{o} t_{1 / 2} \operatorname{mix} \\
(\mathrm{mol} \mathrm{s})\end{array}$ & $\begin{array}{l}C_{o} t_{1 / 2} \text { pure } \\
\text { (mol s) }\end{array}$ \\
\hline \multicolumn{5}{|l|}{ Escherichia coli } \\
\hline \multicolumn{5}{|l|}{ Fragments unreassociated $=1.05 \%$} \\
\hline \multicolumn{5}{|l|}{ Fragment size $=400$} \\
\hline \multicolumn{5}{|l|}{ [Range $=190-820 \mathrm{bp}]$} \\
\hline Unique Asymptotic $95 \% \mathrm{Cl}$ & 100.00 & $0.375(0.23-0.52)$ & 2.67 & 2.67 \\
\hline \multicolumn{5}{|l|}{ Ixodes scapularis } \\
\hline \multicolumn{5}{|l|}{ Short fragments } \\
\hline \multicolumn{5}{|l|}{ Fragments unreassociated $=7 \%$} \\
\hline \multicolumn{5}{|l|}{ Fragment size $=300 \mathrm{bp}$} \\
\hline \multicolumn{5}{|l|}{$[$ Range $=150-920 \mathrm{bp}]$} \\
\hline Highly repetitive Asymptotic $95 \% \mathrm{Cl}$ & $26.7(7.22-46.13)$ & $60.75(0-209.4)$ & 0.02 & 0.004 \\
\hline Middle repetitive Asymptotic $95 \% \mathrm{Cl}$ & $39.5(26.61-52.29)$ & $0.1734(0-0.4029)$ & 5.77 & 2.28 \\
\hline Unique Asymptotic $95 \% \mathrm{Cl}$ & $33.9(21.96-45.89)$ & $0.000765(0-0.00167)$ & 1307.19 & 443.40 \\
\hline \multicolumn{5}{|l|}{ Long fragments } \\
\hline \multicolumn{5}{|l|}{ Fragments unreassociated $=15 \%$} \\
\hline \multicolumn{5}{|l|}{ Fragment size $=1800 \mathrm{bp}$} \\
\hline \multicolumn{5}{|l|}{ [Range $=900-7200 \mathrm{bp}]$} \\
\hline Highly repetitive Asymptotic $95 \% \mathrm{Cl}$ & $58.3(46.42-70.15)$ & $0.3755(0.0465-0.7045)$ & 0.94 & 0.38 \\
\hline Unique Asymptotic $95 \% \mathrm{Cl}$ & $20.8(11.49-30.22)$ & $0.000584(0-0.00309)$ & 4854.37 & 800.97 \\
\hline \multicolumn{5}{|l|}{ Boophilus microplus } \\
\hline \multicolumn{5}{|l|}{ Short fragments } \\
\hline \multicolumn{5}{|l|}{ Fragments unreassociated $=7.0 \%$} \\
\hline \multicolumn{5}{|l|}{ Fragment size $=300 \mathrm{bp}$} \\
\hline \multicolumn{5}{|l|}{ [Range $=80-950]$} \\
\hline Foldback & 0.82 & & & \\
\hline Highly repetitive Asymptotic $95 \% \mathrm{Cl}$ & $30.92(3.11-58.72)$ & $33.66(0-84.1720)$ & 0.03 & 0.01 \\
\hline Middle repetitive Asymptotic $95 \% \mathrm{Cl}$ & $38.14(31.51-44.78)$ & $0.0488(0.0134-0.0842)$ & 20.49 & 7.82 \\
\hline Unique Asymptotic $95 \% \mathrm{Cl}$ & $30.12(23.70-36.55)$ & $0.000220(0.000029-0.000410)$ & 4545.46 & 1369.09 \\
\hline \multicolumn{5}{|l|}{ Long fragments } \\
\hline \multicolumn{5}{|l|}{ Fragments unreassociated $=8.0 \%$} \\
\hline \multicolumn{5}{|l|}{ Fragment size $=1800$} \\
\hline \multicolumn{5}{|l|}{$[$ Range $=800-8200]$} \\
\hline Highly repetitive Asymptotic $95 \% \mathrm{Cl}$ & $46.06(29.83-62.29)$ & $5.3374(0-11.3720)$ & 0.19 & 0.09 \\
\hline Unique Asymptotic $95 \% \mathrm{Cl}$ & $51.93(44.31-59.55)$ & $0.0160(0.0064-0.0255)$ & 62.50 & 32.46 \\
\hline
\end{tabular}

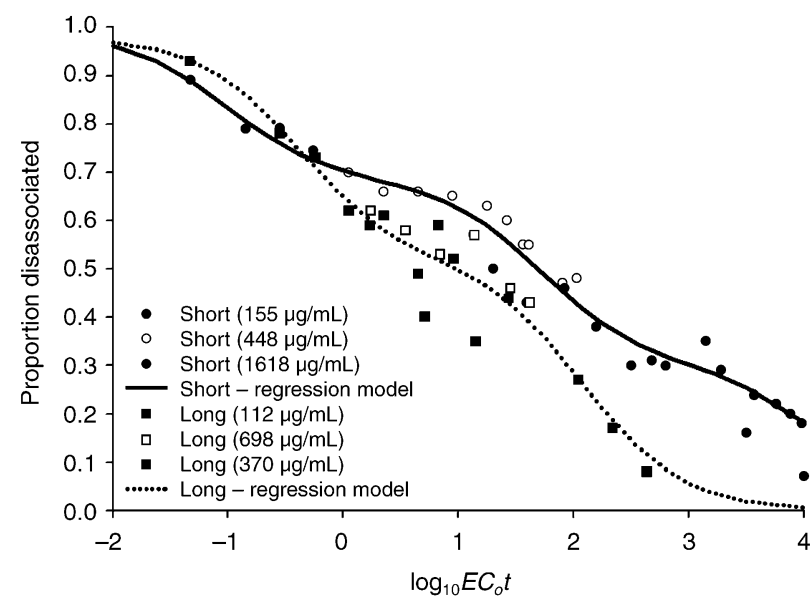

Figure 2. Reassociation of Boophilus microplus DNA sheared to short and long fragment sizes. The short curve represents the least squares solution with four components [foldback (FB), highly repetitive (HR), moderately repetitive (MR), and unique sequences]. The long curve represents the least squares solution with three components (FB, HR, and unique sequences).
MR) (Fig. 1). Estimates of genome size were obtained with the equation:

genome size $=C_{o} t_{1 / 2}$ (unique) $\times\left(0.0044 \mathrm{pg}\right.$ or $4.2 \times 10^{6} \mathrm{bp}$

$$
\text { DNA) } / C_{o} t_{1 / 2} \text { (E. coli) }
$$

The I. scapularis $C_{o} t_{1 / 2}$ (unique) $=1307 \mathrm{~mol}$ s and thus the haploid genome contains c. $2.15 \mathrm{pg}\left(2.1 \times 10^{3} \mathrm{Mbp}\right)$ of DNA with $\left(95 \% \mathrm{Cl}: 0.978 \mathrm{pg}-\infty ; 9.42 \times 10^{2} \mathrm{Mbp}-\infty\right)$. A haploid genome size of $2.37 \mathrm{pg}\left(2.3 \times 10^{3} \mathrm{Mbp}\right)$ was estimated for I. scapularis using cell flow cytometry (C. Hill, S. Wikel \& S. Johnston, pers. comm.).

If a genome is of the long period interspersion type, the reassociation rate of long unique fragments can be predicted using the estimated reassociation rate of short fragments in the equation:

Predicted rate $($ long $)=$ Estimated rate $($ short $) \times \sqrt{L 2 / L 1}$

where $L 1$ and $L 2$ are, respectively, the average lengths of the short and long fragments. If, however, the observed reassociation rate of long unique fragments is substantially 
different than predicted this suggests a pattern of short period interspersion. The observed rate can be faster than predicted if $L 2$ lengths occur in a narrow size range. A homogeneous distribution of long fragments each containing both unique and repetitive DNA will reassociate at the same rate as repetitive sequences. However, obtaining long fragments of uniform size requires gel purification or collection of fractions on a $\mathrm{CsCl}$ gradient and is seldom achieved. For these reasons, the rate with which long fragments reassociate is usually slower than predicted. Substantial hybridization seen late in the long fragment curve either represents reassociation of unique fragments that are shorter than the mean size of the long fragments or is indicative of a mixture of both long and short interspersed elements.

The observed reassociation rate of long fragments in I. scapularis $\left(0.0006 / \mathrm{mol} \mathrm{s} ; \log _{10}\left(E C_{0} t_{1 / 2}\right)=3.23 \mathrm{~mol} \mathrm{~s}\right)$ is substantially different than predicted $\left(0.0019 / \mathrm{mol} \mathrm{s} ; \log _{10}\left(E C_{o} t_{1 / 2}\right)\right.$ $=2.73 \mathrm{~mol} \mathrm{~s}$ ), suggesting primarily a short period interspersion pattern. At $3.23 \mathrm{~mol} \mathrm{~s}$, c. $80 \%$ of the long DNA had reassociated. Note that the reassociation of the long fragments parallels the reassociation seen with short fragments (compare short and long regression models between 3 and $4 \log _{10}\left(E C_{o} t_{1 / 2}\right)$ in Fig. 1. The remaining c. $20 \%$ of fragments probably therefore consisted of unique DNA. This observation suggests that the I. scapularis genome contains a mixture of both long and short interspersed elements.

The $B$. microplus genome also contains a high percentage (69\%) of repetitive DNA ( $31 \% \mathrm{HR}$ and $38 \% \mathrm{MR}$ ) (Fig. 2). The $B$. microplus $C_{o} t_{1 / 2}$ (unique) $=4545 \mathrm{~mol}$ s and the haploid genome thus contains c. $7.5 \mathrm{pg}$ or $7.1 \times 10^{9} \mathrm{bp}(95 \% \mathrm{Cl}$ $\left.4.02-56.8 \mathrm{pg} ; 3.84 \times 10^{3}-54.2 \times 10^{3} \mathrm{Mbp}\right)$. In contrast with l. scapularis, the observed reassociation rate of long fragments $\left(0.0160 / \mathrm{mol} \mathrm{s} ; \log _{10}\left(E C_{o} t_{1 / 2}\right)=1.80 \mathrm{~mol} \mathrm{~s}\right)$ is much faster than predicted $\left(0.0005 / \mathrm{mol} \mathrm{s} ; \log _{10}\left(E C_{0} t_{1 / 2}\right)=3.27\right.$ $\mathrm{mol} \mathrm{s})$, characteristic of a short period interspersion pattern. By $1.80 \mathrm{~mol} \mathrm{~s}$, c. $65 \%$ of the long DNA had reassociated suggesting that $c .35 \%$ of remaining fragments consisted of short and long unique DNA indicative again of a mixture of long and short period interspersion.
Repeat frequency and complexity estimates for HR, MR, and unique fractions of both $I$. scapularis and B. microplus are presented in Table 2. The I. scapularis genome contains HR DNA with low complexity; HR elements occur with an average frequency of $c .80000$ copies/haploid genome. MR elements have greater complexity with an average frequency of $c$. 230 copies/haploid genome. The B. microplus genome contains HR DNA with very low complexity; with an average frequency of $c .153000$ copies/haploid genome. MR elements occur with an average frequency of c. 220 copies/haploid genome.

Amblyomma americanum is the other metastriate tick in which genome size and organization have been determined. The size of that genome is $1.04 \times 10^{3} \mathrm{Mbp}$ composed of four kinetic components (4\% FB, $18 \% \mathrm{HR}, 42 \%$ MR and $36 \%$ unique DNA) (Palmer et al., 1994). In contrast with the two ticks examined in the present study, HR and MR elements are distributed in a long period interspersion pattern. The HR DNA of $A$. americanum is of extremely low complexity with c. 238000 copies/haploid genome.

The genome size and organization data we generated for I. scapularis and B. microplus were examined with respect to the same data collected in $A$. americanum as well as in eighteen insects (Palmer \& Black, 1997). The percentages of each genome consisting of $\mathrm{FB}+\mathrm{HR}, \mathrm{MR}$, and unique DNA are plotted in three dimensions for each of the twentyone arthropod species (Fig. 3). Tick genomes fall into a cluster separate from insects. Tick genomes have a higher percentage of MR DNA and a lower percentage of unique DNA. Canonical discriminant analysis (PROC CANDISC SAS 9.1; SAS, 2002) showed that canonical discriminants corresponding to \%MR, and \%unique DNA accounted for $90.6 \%$ of the total variance and that the three clusters depicted in Fig. 3 are significantly differentiated (Wilks' $\left.\lambda=0.148, F=13.57, P_{(4,34 \text { df })}<0.0001\right)$. MR elements in both tick and insect genomes have similar complexities of $c$. 100500 copies/haploid genome. Only genome sequencing will reveal what proportion of this large amount of MR DNA in ticks consists of multigene families and transposable elements.

Table 2. Amount and repeat number for repetitive and unique sequences

\begin{tabular}{|c|c|c|c|c|}
\hline Species & Amount (pg) & Complexity $(b p)^{*}$ & Complexity (pg) & Repetitive frequency \\
\hline \multicolumn{5}{|l|}{ Ixodes scapularis } \\
\hline Foldback & - & - & & - \\
\hline Highly repetitive & 0.573 & $6.91 \times 10^{3}\left(3.47 \times 10^{3}-\infty\right)$ & $7.23 \times 10^{-6}\left(3.63 \times 10^{-6}-\infty\right)$ & 80000 \\
\hline Middle repetitive & 0.848 & $3.58 \times 10^{6}\left(2.04 \times 10^{6}-\infty\right)$ & $3.75 \times 10^{-3}\left(2.14 \times 10^{-3}-\infty\right)$ & 227 \\
\hline Unique & 0.729 & $6.97 \times 10^{8}\left(4.32 \times 10^{8}-\infty\right)$ & $7.31 \times 10^{-1}\left(4.53 \times 10^{-1}-\infty\right)$ & 1.0 \\
\hline \multicolumn{5}{|c|}{ Boophilus microplus } \\
\hline Foldback & 0.061 & & & \\
\hline Highly repetitive & 2.316 & $1.45 \times 10^{4}\left(1.1 \times 10^{4}-\infty\right)$ & $1.51 \times 10^{-5}\left(1.11 \times 10^{-5}-\infty\right)$ & 153000 \\
\hline Middle repetitive & 2.857 & $1.23 \times 10^{7}\left(8.37 \times 10^{6}-3.7 \times 10^{7}\right)$ & $1.29 \times 10^{-2}\left(8.76 \times 10^{-3}-3.88 \times 10^{-2}\right)$ & 222 \\
\hline Unique & 2.256 & $2.15 \times 10^{9}\left(1.40 \times 10^{9}-1.29 \times 10^{10}\right)$ & $2.26\left(1.47-1.35 \times 10^{1}\right)$ & 1 \\
\hline
\end{tabular}

${ }^{*}$ The complexity in base pairs of each sequence class is calculated based on a genome size in $E$. coli of $4.2 \times 10^{6}$ bp which reassociates with a $C_{0} t_{1 / 2}$ of 2.67 mol s. 


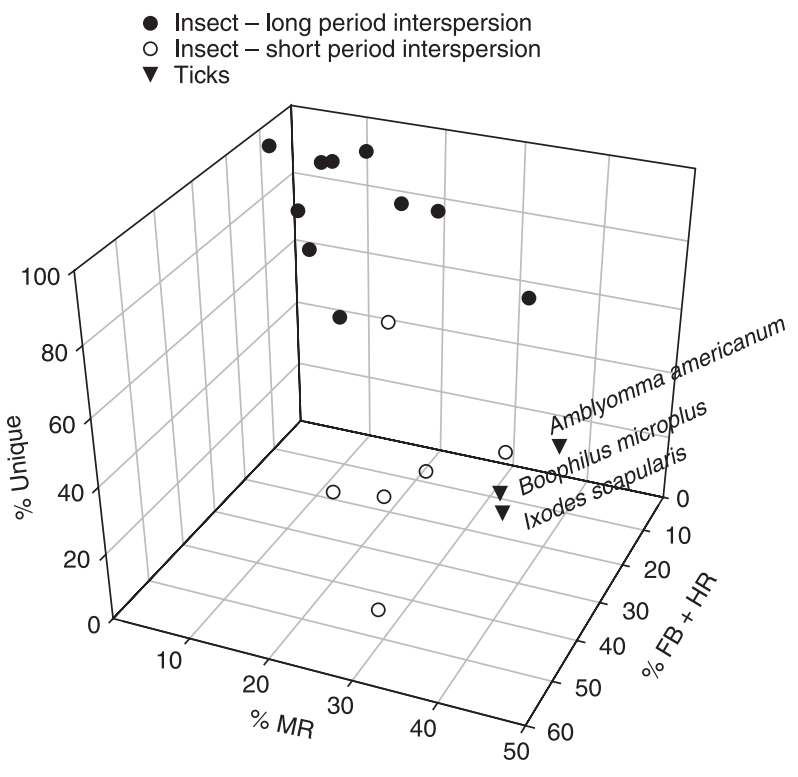

Figure 3. Comparison of the genome composition in Ixodes scapularis, Boophilus microplus, and Amblyomma americanum with eighteen other insect species published to date.

The HR component of tick genomes has a much lower complexity (80 000-238 000 copies/haploid genome) than the HR of insects. The lowest complexity in insects was detected in a strain of Aedes albopictus from Calcutta, India with 49900 copies/haploid genome (Black \& Rai, 1988). The low complexity of HR DNA in ticks is likely to be manifested in the upcoming genome projects as an abundance of HR elements of very similar sequence. This will be of benefit in terms of being able to easily identify repetitive elements in genomic sequences but may be a drawback in the identification of overlapping sequences or overlapping BAC ends. The overall length of the I. scapularis linkage map (Ullmann et al., 2003) was estimated to be $3166 \mathrm{~cm}$, providing a resolution of $663 \mathrm{~kb} / \mathrm{cm}\left(2.1 \times 10^{3} \mathrm{Mbp} / 3166 \mathrm{~cm}\right)$. A resolution of $c .700 \mathrm{~kb} / \mathrm{cm}$ compares favourably to the average $1100 \mathrm{~kb} / \mathrm{cm}$ resolution in Anopheles gambiae (Dimopoulos et al., 1996) or the $1000-3400 \mathrm{~kb}$ resolution for Aedes aegypti (Brown et al., 2001). A map of this resolution has a higher probability of being successfully used in mappedbased positional cloning of candidate genes in I. scapularis.

Enormous variation exists in the amounts and organization of repetitive DNA at the family level in hard ticks. Ten-fold variation in genome size was also seen in mosquitoes (Black \& Rai, 1988). However, a major difference is that the smallest tick genome is equal in size to the largest mosquito genome. Cavalier-Smith (1978) found a positive correlation between genome size, cell cycle length, and overall development time. Most ticks develop slowly from eggs to adults over a period of months and years while the average mosquito life cycle is generally completed in weeks. However, the $B$. microplus genome is three times larger than the
I. scapularis genome and yet its life cycle can be completed in 3-4 weeks while the $I$. scapularis life cycle requires at least 18 months. The most that can be predicted from the three tick genome measurements made to date is that tick genomes will be large, highly variable in size and consist largely of MR DNA.

\section{Experimental procedures}

\section{Preparation of DNA}

Field-collected Ixodes scapularis females (NWS Earle, NJ) were allowed to oviposit and the resulting egg batches were collected. Frozen eggs from the Deutsch strain and the Munoz strain were utilized for DNA isolation in Boophilus microplus. Egg batches were divided into $50 \mathrm{mg}$ samples that were subsequently frozen and ground in liquid nitrogen. Genomic DNA was isolated utilizing the CTAB (hexadecyltrimethylammonium bromide) method (Black \& DuTeau, 1997). DNA was then purified on caesium chloride gradients (Palmer \& Black, 1997). These procedures yielded c. $4.5 \mathrm{mg}$ I. scapularis DNA and c. $2.9 \mathrm{mg} \mathrm{B.} \mathrm{microplus} \mathrm{DNA.} \mathrm{Escherichia} \mathrm{coli}$ DNA (strain B) was purchased from Sigma (D-2001; St Louis, MO).

\section{Preparation and sizing of DNA fragments}

Tick and E. coli DNA (1-2 mg) were dissolved in $5 \mathrm{ml} 1 \times$ sonication buffer (Sambrook et al., 1989) in a $15 \mathrm{ml}$ conical polypropylene tube. A mean fragment length of $1800 \mathrm{bp}$ was obtained by cooling the sonication mixture on a dry ice/ethanol bath and sonicating (Branson sonifier, Model S110; Danbury, CT) for $30 \mathrm{~s}$ at the lowest setting. A mean fragment length of $300 \mathrm{bp}$ was obtained by sonicating for a total of 45 cycles of $30 \mathrm{~s}$ bursts, with cooling of the DNA between cycles in a dry ice/ethanol bath. Average fragment length was determined on $0.75 \%$ agarose gels.

\section{DNA reassociation}

Following sonication, DNA fragments were ethanol precipitated and resuspended in $0.12 \mathrm{M}$ phosphate buffer of $\mathrm{pH} 7.0$ (PB) at approximate concentrations of $100 \mu \mathrm{g} \mathrm{DNA} / \mathrm{ml}$ for low $C_{o} t$ values, and $500 \mu \mathrm{g} / \mathrm{ml}$ for mid $C_{o} t$ values. DNA was dissolved in $0.4 \mathrm{M} \mathrm{PB}$ at a concentration of $c$. $1000 \mu \mathrm{g} / \mathrm{ml}$ for high $C_{o} t$ values. When reassociating in $0.4 \mathrm{M} \mathrm{PB}$, equivalent $C_{o} t$ values were calculated by multiplying the $C_{o} t$ value by 4.9 (Britten et al., 1974). Approximately $40 \mu \mathrm{g}$ DNA was used for each point on the $C_{o} t$ curve and $7-13$ points were collected for each of the three reassociation conditions.

Optimal conditions for hydroxyapatite chromatography were determined using E. coliDNA (Palmer \& Black, 1997). Conditions optimized were: (1) rate of air flow to push elutant through a column; (2) $0.3 \mathrm{M}$ PB wash volume (6-12 $\mathrm{ml}$ in increments of $2 \mathrm{ml}) ;$ (3) elution volume of $0.12 \mathrm{M} \mathrm{PB}$ and $0.4 \mathrm{M} \mathrm{PB}(4-10 \mathrm{ml}$ in increments of $2 \mathrm{ml})$; (4) hydroxyapatite packed bed volume $(1-3 \mathrm{ml}$ in increments of $0.5 \mathrm{ml})$. Final conditions used a low air flow rate, $12 \mathrm{ml}$ wash volume ( $2 \times 6 \mathrm{ml}$ washes), $8 \mathrm{ml}$ elution volume $(2 \times 4 \mathrm{ml}$ washes), and $2 \mathrm{ml}$ packed hydroxyapatite bed volume. Kinetic parameters were estimated with non-linear regression (PROC NLIN SAS 9.1) using the source code described by (Palmer \& Black, 1997).

\section{References}

Belongia, E.A. (2002) Epidemiology and impact of coinfections acquired from Ixodes ticks. Vector Borne Zoonotic Dis 2: 265-273. 
Black, W.C. IV and DuTeau, N.M. (1997) In: The Molecular Biology of Insect Disease Vectors: a Methods Manual (Crampton, J.M., Beard, C.B. and Louis, C., eds), pp. 361-373. Chapman \& Hall Publishers, New York.

Black, W.C. IV and Rai, K.S. (1988) Genome evolution in mosquitoes: intraspecific and interspecific variation in repetitive DNA amounts and organization. Genet Res 51: 185-196.

Bram, R.A., George, J.E., Reichar, R.E. and Tabachnick, W.J. (2002) Threat of foreign arthropod-borne pathogens to livestock in the United States. J Med Entomol 39: 405-416.

Britten, R.J., Graham, D.E. and Neufeld, B.R. (1974) Analysis of repeating DNA sequences by reassociation. Meth Enzymo/29: 363-418.

Brown, S.E., Severson, D.W., Smith, L.A. and Knudson, D.L. (2001) Integration of the Aedes aegypti mosquito genetic linkage and physical maps. Genetics 157: 1299-1305.

Cavalier-Smith, T. (1978) Nuclear volume control by nucleoskeletal DNA, selection for cell volume and cell growth rate, and the solution of the DNA C-value paradox. J Cell Sci $\mathbf{3 4}$ 247-278.

Crain, W.R., Eden, F.C., Pearson, W.R., Davidson, E.H. and Britten, R.J. (1976) Absence of short period interspersion of repetitive and non-repetitive sequences in the DNA of Drosophila melanogaster. Chromosoma 56: 309-326.

Davidson, E.H., Galau, G.A., Angerer, R.C. and Britten, R.J. (1975) Comparative aspects of DNA organization in metazoa. Chromosoma 51: 253-259.

Dimopoulos, G., Zheng, L., Kumar, V., della Torre, A., Kafatos, F.C. and Louis, C. (1996) Integrated genetic map of Anopheles gambiae: use of RAPD polymorphisms for genetic, cytogenetic and STS landmarks. Genetics 143: 953-960.

Ebel, G.D., Spielman, A., and Telford, S.R. 3rd (2001) Phylogeny of North American Powassan Virus. J Gen Virol 82: 1657-1665.
Epplen, J.T., Diedrich, U., Wagenmann, M., Schmidtke, J. and Engel, W. (1979) Contrasting DNA sequence organisation patterns in sauropsidian genomes. Chromosoma 75: 199-214.

Epplen, J.T., Leipoldt, M., Engel, W. and Schmidtke, J. (1978) DNA sequence organisation in avian genomes. Chromosoma 69: 307-321.

Klompen, J.S.H., Black, W.C., Keirans, J.E. and Norris, D.E. (2000) Systematics and biogeography of hard ticks, a total evidence approach. Cladistics 16: 79-102.

Klompen, H., Dobson, S.J. and Barker, S.C. (2002) A new subfamily, Bothriocrotoninae n. subfam., for the genus Bothriocroton Keirans, King \& Sharrad, 1994 status amend. (Ixodida: Ixodidae), and the synonymy of Aponomma Neumann, 1899 with Amblyomma Koch, 1844. Syst Parasitol 53: 101-107.

Krause, P.J. (2002) Babesiosis. Med Clin North Am 86: 361-373. Lewin, B. (1980) Gene Expression. Wiley, New York.

Palmer, M.J., Bantle, J.A., Guo, X. and Fargo, W.S. (1994) Genome size and organization in the ixodid tick Amblyomma americanum (L.). Insect Mol Biol 3: 57-62.

Palmer, M.J. and Black, W.C.I. (1997) The Molecular Biology of Insect Disease Vectors: a Methods Manual (Crampton, J.M., Beard, C.B. and Louis, C., eds), pp. 172-190. Chapman \& Hall, London; New York.

Sambrook, J., Fritsch, E.F. and Maniatis, T. (1989) Molecular Cloning: a Laboratory Manual, 2nd edn, Cold Spring Harbor Press, Cold Spring Harbor, NY.

Samols, D. and Swift, H. (1979) Genomic organization in the flesh fly Sarcophaga bullata. Chromosoma 75: 129-143.

SAS (2002). SAS Institute Inc, Cary, NC.

Sonenshine, D.E. (1991) Biology of Ticks, Oxford Press, New York.

Ullmann, A.J., Piesman, J., Dolan, M.C. and Iv, W.C. (2003) A preliminary linkage map of the hard tick, Ixodes scapularis. Insect Mol Biol 12: 201-210. 